\title{
Postharvest losses of perishables in Brazil: what do we know so far?
}

\author{
Gilmar Paulo Henz \\ Embrapa - Secretaria de Inteligência e Macroestratégia, Brasília-DF, Brasil; gilmar.henz@embrapa.br
}

\begin{abstract}
Although difficult to pin down an exact figure, the idea that postharvest losses (PHL) of perishables in Brazil stand at 30-45\% has been widely accepted. In spite of the modernization of production systems and the logistics and distribution of perishables in the last decades, postharvest losses continue to be a persistent and relevant problem. However, little is known about what has already been published on the subject. This work addresses precisely this issue, based on a comprehensive survey of publications on PHL of fruits and vegetables. Bibliographic searches were performed at the Embrapa's library system, Google Scholar and SciELO. Several publications on PHL of fruits and vegetables were reviewed and grouped according to their scope and objectives into three major categories: (1) PHL studies: estimates, measurements, research projects, reviews; (2) postharvest technologies: application of technologies, studies of postharvest physiology, diseases and/or mechanical damage; (3) economics: studies of economics, logistics and management. Results of this analysis are discussed in a historic perspective and mainly in what they reveal of the impact of social and technological development on the studies of PHL in horticultural crops.
\end{abstract}

Keywords: waste, fruits, vegetables, estimates, publications.

\section{RESUMO}

Perdas pós-colheita de hortícolas no Brasil: o que sabemos até agora?

No Brasil, é amplamente disseminada a ideia de que as perdas pós-colheita de produtos hortícolas situam-se em 30-45\%. É difícil estimar um número exato, mas, apesar da modernização dos sistemas produtivos e da logística na distribuição de produtos hortícolas nas últimas décadas, as perdas pós-colheita continuam a ser um problema persistente e relevante. Entretanto, sabe-se pouco sobre o que já foi publicado sobre o tema. Este trabalho aborda precisamente esta questão, tendo como base um levantamento abrangente das publicações sobre perdas pós-colheita de frutas e hortaliças. As buscas foram realizadas no sistema de bibliotecas da Embrapa, Google Acadêmico e SciELO. De acordo com seu objetivo e escopo, as publicações foram agrupadas em três categorias de documentos: (1) estudos sobre perdas pós-colheita: estimativas, aferições, projetos de pesquisa, revisões; (2) tecnologias de pós-colheita: aplicação de tecnologias, estudos de fisiologia, doenças e/ou dano mecânico; e (3) economia: estudos de economia, logística e gestão. Os resultados desta análise são discutidos em uma perspectiva histórica e, especialmente, no que eles revelam do impacto do desenvolvimento social e tecnológico sobre o estudo de perdas pós-colheita de frutas e hortaliças.

Palavras-chave: descarte, frutas, hortaliças, estimativas, publicações.

Received on November 1, 2016; accepted on March 2, 2017

$I^{2}$ the last decades, the domestic supply of fruits and vegetables in Brazil has been secured by a remarkable progress in the adoption of modern production techniques and the implementation of more efficient distribution channels. Nonetheless, the country still faces considerably high postharvest losses (PHL) for fruits and vegetables, estimated as 30-45\% for Latin American countries (FAO, 2011; HLPE, 2014).

The first publications on PHL in Brazil began to emerge in the 1970s, coinciding with a period of agricultural development and economic growth. Historically, coefficients of postharvest losses of main food crops were set to calculate the annual figures of the internal supply balance by the
"Fundação Getúlio Vargas" to estimate the availability of agricultural products. These fixed loss indices were used indiscriminately, without considering the annual variations in production, climatic conditions or the adoption of new technologies that could impact losses (Carvalho, 1992).

Since the 1980s, agricultural higher education and research in Brazil have been strengthened by governmental investments. Plant Physiology, Plant Pathology, Plant Breeding, Horticulture, Food Sciences and other Postharvest related areas had a remarkable progress. Thus, new generations of teachers, students and researchers have begun to develop and adapt technologies to improve fruit and vegetable production and postharvest handling systems. From 1990 onwards, many publications on postharvest losses appeared in different formats, such as scientific articles, reviews, books, book chapters, technical documents, reports, academic papers, papers and abstracts presented at scientific meetings and congresses, as well as editorials and newspaper articles.

These publications dealt with various issues related to losses, usually aiming at reducing PHL and identifying causes. In a recent Horticultura Brasileira cover article, Lana (2013) considered PHL reduction and quality maintenance as the greatest challenges of postharvest technology on vegetable crops in Brazil. The main obstacles to reduce losses are inadequate infrastructure, deficiency in 
postharvest technology transfer to all segments, unavailability of equipment and technology for smallholder farmers and, especially, a more efficient and fair commercialization system.

A report by the High Level Panel of Experts on Food Security and Nutrition of the Committee on World Food Security (HLPE, 2014) recommends undertaking four parallel mutually supportive tracks to reduce globally the impact of food losses and waste (FLW), the first one being improving data collection and knowledge sharing on the subject. Kitinoja \& Kader (2015) gathered the existing information on measuring PHL of fresh fruits and vegetables in developing countries into a single document to be used as a basis for future research and method development. This publication had just four Brazilian-borne citations, three of them written in Portuguese. Hence, it's possible that some relevant information in PHL produced in Brazil are unknown or unavailable internationally because they are published in Portuguese or difficult to retrieve or recover.

In 2015, the "ADM Institute for the Prevention of Postharvest Loss" at the University of Illinois, UrbanaChampaign, United States, together with FAO and other international institutions, organized the "First International Congress on Postharvest Loss Prevention - Developing Measurement Approaches and Intervention Strategies for Smallholders", held in Rome, Italy, in October 2015. In this congress, two reviews on PHL of perishables in Brazil were presented (Henz, 2015; Péra et al., 2015).

The paper of Péra et al. (2015) is a meta-analysis of PHL in Brazil with 60 publications selected according to the product (vegetables, fruits, grains, cereals, flowers), type of loss (qualitative and quantitative), cause (packaging, handling, transportation, storage, insects, diseases, physiological disorders), methodology (survey, sampling, field or laboratory experiments, reviews, others), metrics (weight loss, physical, nutritional, economic), and year of publication. As result, authors reported that fruits $(45.9 \%)$ and vegetables $(27.9 \%)$ were the most studied products, while quantitative losses were the main focus of studies $(83.8 \%)$. Storage (43.2\%), packaging and handling (23\%), and transportation $(17.6 \%)$ were the most frequent loss causes identified.

The other Brazilian paper presented at the Congress (Henz, 2015) presented an updated view of PHL of perishables in Brazil, indicating that most of the studies dealt with percentages of losses, actually estimates or approximations, with great variability of results, depending on the product, region and market (retail, wholesale). The main limitations of these surveys were (1) the lack of standardized scientific parameters, based on observations or interviews, and (2) a proper identification of the loss causes.

According to Lana (2016), estimates of losses between $35 \%$ and $55 \%$ for fruits and vegetables in Brazil should be analyzed with caution, considering that they were calculated from a limited database. PHL assessments for vegetable crops in Brazil are characterized by having been carried out in a defined period of time and in a one-off manner by different groups of researchers. In addition, the use of different methodologies makes it difficult to compare results. In the top of it, subjective loss assessments restrain volume quantification and accurate identification of causes.

This paper tries to answer the title's question by making a preliminary inventory of publications on PHL of perishables carried out in Brazil, building on the first recommendation by the HPLE (2014) on improving data collection. In this way, it would be possible to assess what is already known and to identify possible gaps or research demands in Brazil. At the same time, a secondary goal is to publicize the existence of Brazilian documents on PHL of perishables, sharing the information produced in the country with the international community.

\section{Publications on postharvest losses: what had already been studied in Brazil?}

Searches for documents on PHL were conducted in the collection of the Embrapa's library system, Google
Scholar and SciELO (Scientific Electronic Library Online, www.sielo. br). More than 100 publications on PHL have been retrieved, including scientific articles, technical publications, research projects, reports, academic papers (thesis, dissertations, others), reviews, books and chapters, and abstracts and papers presented in scientific meetings. Editorials, opinions and other newspaper releases were not considered in this study.

The selected documents were individually analyzed and categorized according to their scope and main objective into three major groups: (1) focus on postharvest losses: estimates, measurements, research projects, reviews; (2) use of postharvest technologies: application of technologies, studies on postharvest physiology, diseases and/or mechanical damage, and; (3) economic approach: economics, logistics and management studies (Table 1). Due to space limitations in this article, only some of the publications consulted are listed as examples of each category.

\section{Publications focused on postharvest losses}

This category includes publications dealing specifically with PHL of perishables, such as surveys based on estimates and measurements, research projects and reviews in distinct formats (articles, books, reports, others).

1a. Estimates of losses: most of the studies can be considered as subjective estimates, since data were gathered through structured questionnaires and interviews, strongly influenced by the first estimates carried out in the 1970s by SUDENE, the public development agency for the Northeast region. Interviews were carried out with professionals responsible for trading fruits and vegetables in the wholesale markets and street markets. PHL were categorized by the interviewer in the following causes: (a) delay between buying and selling; (b) poor product initial quality; (c) inadequate packaging; (d) inadequate storage; (e) inadequate transportation; (f) adverse weather conditions; (g) other causes (SUDENE, 1971). Several subsequent surveys 
Table 1. Categorization of publications on postharvest losses of horticultural products in Brazil. Brasília, Embrapa, 2016.

\begin{tabular}{|c|c|c|}
\hline Group & Subgroup & Characteristics \\
\hline \multirow[t]{4}{*}{$\begin{array}{l}\text { Post-harvest } \\
\text { losses }\end{array}$} & Estimates & $\begin{array}{l}\text { scientific papers, abstracts, technical and academic publications } \\
\text { data obtained from questionnaires and interviews } \\
\text { focus on estimates (loss percentages) } \\
\text { time period: less than } 12 \text { months } \\
\text { evaluation of many products in one city or state } \\
\text { segment: retailers and wholesalers } \\
\text { identification of loss causes are generic }\end{array}$ \\
\hline & Measurement & $\begin{array}{l}\text { scientific papers, abstracts, technical and academic publications } \\
\text { data obtained from experiments } \\
\text { sampling/direct measurements } \\
\text { loss based on the difference between amount of product purchased (reception) and not } \\
\text { sold (discharged) } \\
\text { initial quality - discard } \\
\text { segment: usually retailer } \\
\text { identification of loss causes (mechanical damage, diseases, physiological) }\end{array}$ \\
\hline & $\begin{array}{l}\text { Research } \\
\text { Projects }\end{array}$ & $\begin{array}{l}\text { research project proposals or final reports } \\
\text { bibliographic review or state of the art } \\
\text { methodology proposed or applied } \\
\text { expected or achieved outcomes } \\
\text { bibliography or cited literature }\end{array}$ \\
\hline & Reviews & $\begin{array}{l}\text { review articles, books (or chapters), technical and academic publications } \\
\text { literature review and bibliographic search } \\
\text { compilation of data and technical information } \\
\text { based on national and international bibliography }\end{array}$ \\
\hline \multirow[t]{2}{*}{$\begin{array}{l}\text { Post harvest } \\
\text { Technologies }\end{array}$} & $\begin{array}{l}\text { Postharvest } \\
\text { technologies }\end{array}$ & $\begin{array}{l}\text { scientific papers, abstracts, technical and academic publications } \\
\text { scientific methodology (experimental design) } \\
\text { specific results by product and/or technology applied (packaging, refrigeration, } \\
\text { hormones, wax, coatings, AC/AM, irradiation, others) } \\
\text { focus on qualitative losses (nutritional composition, appearance, color, firmness) } \\
\text { quantitative loss: mass/fresh weight }\end{array}$ \\
\hline & $\begin{array}{l}\text { Postharvest } \\
\text { diseases and } \\
\text { mechanical } \\
\text { damage }\end{array}$ & $\begin{array}{l}\text { scientific papers, abstracts, technical and academic publications } \\
\text { scientific methodology (experimental design) } \\
\text { loss caused by postharvest diseases and/or mechanical damage } \\
\text { product-specific (fruit or vegetable species) } \\
\text { losses caused by diseases and/or mechanical damage }\end{array}$ \\
\hline \multirow[t]{3}{*}{ Economics } & Economics & $\begin{array}{l}\text { scientific papers, reviews, abstracts, academic publications } \\
\text { economic and physical losses } \\
\text { mathematical models } \\
\text { studies on welfare cost, loss elasticity, marginal cost } \\
\text { loss incremental rate on food prices }\end{array}$ \\
\hline & Logistics & $\begin{array}{l}\text { scientific papers, reviews, abstracts, academic publications } \\
\text { economic and physical losses } \\
\text { mathematical models } \\
\text { models to estimate losses according to variables of the transportation system } \\
\text { building scenarios to loss levels } \\
\text { loss evaluation during transportation }\end{array}$ \\
\hline & Management & $\begin{array}{l}\text { scientific papers, reviews, abstracts, academic publications } \\
\text { economic and physical losses } \\
\text { impact of losses on the availability and marketing of horticultural products } \\
\text { management of purchases, losses and inventory control } \\
\text { retail marketing of horticultural products }\end{array}$ \\
\hline
\end{tabular}


in Brazil were carried out following this methodological approach. Ueno (1976) and Tsunechiro et al. (1994) did surveys on PHL in 42 fruits and vegetables in supermarkets, groceries and street fairs in São Paulo city at two distinct periods (1973/74 and 1991). Ueno (1976) considered that most of the losses occurred in supermarkets due to additional handling and packaging, and a product correction factor was calculated to replace the losses. Tsunechiro et al. (1994) found $10.2 \%$ as the average loss, and considered that reducing losses could increase trade margins due to additional costs for retailers.

1b. Measurement of losses: there are relatively few publications based on measurements, here defined as mass or weight measurement of the discarded part, as opposed to estimates based on questionnaires or interviews. The first article with this approach was published by Lana et al. (2002), who carried out an evaluation of carrot losses in a supermarket in Brasília-DF for a fivemonth period, as a part of a research project listed below (Lana et al., 1999). The cause of losses was categorized in two types of samples, called "Initial Quality" (purchased) and "Discard" (not sold). Losses in carrot ranged from $10 \%$ to $18 \%$ and the main identified causes were mechanical damage, root defects and root wilting.

1c. Research Projects: there are few hard copies of research projects proposals or final reports on $\mathrm{PHL}$ of perishables in Brazil available in libraries. The following three were selected out of other proposals and final reports due to their highly informative value on PHL measurement methods:

- "Research on postharvest practices and development of a method to analyze losses of perishables" (Mukai \& Kimura, 1986): the objective of the project was to identify postharvest handling practices on five vegetables (tomato, potato, onion, cabbage, and carrot) at farmers, wholesalers and retailers in the state of Minas Gerais and then to establish strategies to reduce losses. The estimates of losses for these vegetables were variable, depending on the commercialization stage (wholesale or retail) and period of the year (summer or winter);

- "Evaluation of postharvest losses of horticultural crops in the State of São Paulo" (Carvalho, 1992): the project proposal describes the state of the art on the subject at the time, highlighting the scarcity and precariousness of the information available in Brazil, and the high degree of uncertainty in estimates (Carvalho, 1992). The description of the methodology to be used is an interesting part of the proposal. It aimed at quantifying and identifying PHL causes (mechanical, physiological, pathological), considering the seasonality of supply and origin of 14 fruits and vegetables traded at the CEAGESP wholesale market, in São Paulo. Sampling was based on the Stenvenson's formula for finite populations with unknown variance. Apparently, this project was not implemented, although it served as theoretical framework for other research projects.

- "Levels and values of postharvest losses in supermarkets of a retail chain in the Federal District area" (Lana et al., 1999): the project started in 1998 by evaluating methodologies to assess losses in carrot, tomato and sweet pepper in four supermarkets. Statistical sampling was determined and losses were measured as product initial quality minus the discarded portion. For carrot, physical loss was estimated by the identification of root defects (cracks, splits, broken, diseases, mechanical damage, wilt, other) and size. The project yielded many technical publications and the methodology applied was subsequently used by other researchers.

1d. Reviews: There are several documents about PHL of fruits and vegetables published in Brazil in the last 40 years that can be considered in general terms as reviews. These publications are based on bibliographic research and content replication, such as concepts, data and other information, usually produced by other authors or originating from other references. Documents of this category are available as books or chapters, review articles, reports, case studies and technical publications:
- Books: Several books published in Brazil on Postharvest include losses as a topic in one of the chapters or directly in the text. Here, only two are presented because they approach the subject from different angles.

The book "Fisiologia e Manuseio Pós-Colheita de Produtos Hortícolas" (Postharvest Physiology and Handling of Horticultural Products) is eminently scientific and technical, with a specific chapter on PHL, which discusses definitions and terminology, methods of evaluation, causes, and methods to reduce postharvest losses (Chitarra \& Chitarra, 1990). An updated version of the book was released in 2005, and the chapter on postharvest losses was comprehensively expanded and revised (Chitarra \& Chitarra, 2005).

The book "Panela Furada: o Incrível Desperdício de Alimentos no Brasil" (Pan Holes: The Incredible Food Waste in Brazil) is more investigative and journalistic and describes comprehensively the state of the art on food losses and wastage in Brazil, gathering the scarce statistics and studies available at that time (Borges, 1991).

- Specific PHL review articles: There are several reviews and generic articles on PHL of horticultural products widely cited in Brazil. Vilela et al. (2003) discuss the weight of losses in the entire vegetable chain and identify the main causes and possible solutions. As economic consequences of losses, additional costs are transferred to the final consumer and retailers maintain their marketing margin regardless the level of losses. Another much-cited review on losses of perishables was published by Martins \& Farias (2002). The types and causes of losses in agricultural products are discussed, as well as questions related to the increase of agricultural productivity and food availability.

- Technical publications: Research institutions and universities have produced many technical publications on PHL in the last four decades. Usually, publications are product-specific (fruit or vegetable crops) and/or subject-specific, such as handling practices, packaging, storage, diseases, mechanical damage, 
and others. Examples of this type of publication are a booklet about handling practices to prevent postharvest losses in fruits and vegetables (Cenci et al., 1997), a book with questions and answers about postharvest of vegetable crops (Luengo \& Calbo, 2013), and a technical document with identification of some of the main problems causing losses in the postharvest chains of horticultural products (Freire Júnior \& Soares, 2014).

\section{Application of Postharvest Technologies}

Since 1980, several graduation courses in Agronomy, Plant Physiology, Horticultural Sciences, Plant Pathology and Food Technology, both at M.Sc. and $\mathrm{Ph} . \mathrm{D}$. levels, were opened in Brazilian universities. At the same time, distinct aspects of postharvest of horticultural products began to be investigated. As result, there are a large number of professionals with knowledge on postharvest and related areas that have begun to produce all sorts of publications using postharvest technologies.

2a. Postharvest technologies: since the 1990s, several scientific articles on postharvest technologies of perishables have been published in Brazil. Their main objectives were to evaluate the impact of the use of specific technologies on the shelf life and quality of fruits and vegetables compared to control treatments. Some of the technologies evaluated were: refrigeration, packaging, waxes and other coatings, controlled/modified atmosphere, hormones and other substances, irradiation, ozone, UV-C light, essential oils. The parameters most used in the evaluation were related to qualitative aspects, such as changes in final product contents (soluble solids, vitamins, and titratable acidity), firmness and color. Quantitative losses are usually assessed by mass weighing (fresh matter). In some cases, the discarded portion of the product is compared to a given saleable standard, mostly based on appearance. Most of these papers do not deal specifically with postharvest losses or show data of unsaleable products.

2b. Postharvest diseases and mechanical damage: a significant part of the published scientific papers is related to incidence of postharvest diseases and mechanical damage, two of the main PHL causes for horticultural products. In Brazil, diseases and mechanical damage in fruits and vegetables are directly linked to inadequate postharvest handling practices, such as rough handling, improper packaging, transportation in trucks without refrigeration on poorly maintained roads, and the incidence of high temperatures in most part of the country.

3. Economics, logistics and management

Since the 1970 s, many studies on economics and logistics related to postharvest losses of perishables have been published in Brazil. Only after the 2000s, management-related studies begin to emerge, such as loss prevention in supermarkets, distribution and logistics, stock management and other aspects of administration.

3a. Economy: Brandt et al. (1974) analyzed the commercialization and economic consequences of PHL of tomato, sweet peppers, lettuce and cabbage grown in Manaus, State of Amazonas, Northern Brazil. Average PHL of $15 \%$ were determined for tomato; $11 \%$ for lettuce and cabbage; and $10 \%$ for sweet peppers. The marginal propensity to losses and yield elasticity were calculated. Resende (1979) identified and analyzed the causes and effects of physical losses in the commercialization of tomato (31.14\% loss) and cabbage (26.55\% loss) in the State of Minas Gerais. Losses net social cost reached $25.8 \%$ and $27.5 \%$ for tomato and cabbage, respectively. Farmers were more impaired than consumers in terms of welfare, with losses in marketing regarded as income transfer.

3b Logistic studies: Caixeta Filho (1999) published a case study on losses in the transportation of fruits and vegetables in São Paulo, Brazil. Using mathematical models, scenarios were developed taking into account the adoption of technologies that potentially could reduce losses of tomatoes and pineapples at the CEAGESP, the largest wholesale market in Brazil. Wholesalers were the main players in the chain and had oligopoly power, but seemed unwilling to adopt technologies that increase costs. An updated version of this model was presented at the First International Congress on Postharvest Loss Prevention in 2015. In 1996, Costa \& Caixeta Filho published a case study on losses in transportation and marketing of tomatoes in the state of São Paulo involving three segments (producer, broker and retailer), with estimated losses of $10 \%$ in transportation. Consumers would always be impaired by absorbing the price increase caused by the reduction in the quantity offered.

3c. Management: from the 1990s, supermarkets started to play a fundamental role in the distribution of fruits and vegetables in Brazil. For this reason, studies of distribution, stock management and losses began to be carried out by management professionals. Most of the information on this subject is available only as abstracts presented in scientific meetings, and just a few scientific articles were published. Foscaches et al. (2012) carried out a study on logistics and postharvest handling of vegetables in eight cities in the states of Mato Grosso do Sul, São Paulo and Paraná, with average $5.6 \%$ losses for fruits, and $8 \%$ and $3.6 \%$ respectively for high and low perishable vegetables. Silva \& Martins (2010) showed that more efficient logistics measures could reduce PHL, as described in the study on the transportation, handling and storage of papaya, strawberry and leafy vegetables at CEASA-MG, the main wholesale market of the state of Minas Gerais. Nevertheless, they were not adopted due to the additional costs they imply, which would be transferred to consumers. In addition, wholesalers operate with relatively low profit margins and had no interest in investing in logistics innovations.

Publications on postharvest losses: lessons learned

There is a relatively large number of publications on postharvest losses in the last decades, which is an evidence of the relevance of the subject to the Brazilian scientific community. Until the 1970s, there was no aggregated information about PHL of horticultural 
products in Brazil. The categorization of the publications produced in the studied period demonstrates the degree of diversity of the authors' academic background, such as Agronomy, Food Science, Economics and Management. By reviewing what has been published so far, it was possible to notice three distinct periods on the studies about PHL of horticultural products. From 1970 to 1990 , there was an agronomic and economic emphasis, with efforts in understanding the effect of losses in the price of products, determining percentages of losses and identifying preliminarily the causes. Since the 1990s, the focus shifted to the application of postharvest technologies aimed at reducing the qualitative and quantitative losses of horticultural products, such as packaging and refrigeration, for example, and to study losses caused by diseases or mechanical damage. In the last two decades, distribution channels and management began to be studied due to changes in the marketing of fresh fruits and vegetables in Brazil.

Overall, publications on PHL of fruits and vegetables in Brazil are too generic and/or represent very particular situations. These "instant snapshots" are usually descriptive, presenting percentages of losses, with less emphasis on identifying or discussing properly the causes. Therefore, these publications had little practical effect or potential capacity to modify the situation they described. Even so, some of publications are interesting because they reveal details of postharvest handling systems and marketing chain of many Brazilian agri-food systems, a highly complex universe that undergoes rapid changes due to economic factors.

\section{Research on PHL measurement}

The scarcity of more comprehensive and in-depth publications and research results on PHL of horticultural products in Brazil may be explained by the difficulties in carrying out this type of survey, as pointed out for some authors. Measurement and identification of the causes of losses requires a very large operational effort, with the mobilization of financial resources and a multidisciplinary team to carry out the activities for a reasonable period of time. For this reason, most publications are estimates, obtained through questionnaires and/or interviews.

It is amazing that some research projects on PHL measurement were effectively carried out in Brazil, even though facing all sort of difficulties, such as those in Minas Gerais state (Mukai \& Kimura, 1986; Rezende, 1992) and the Federal District (Lana et al., 1999, 2002). Mukai \& Kimura (1986) project final report is very rich and informative on the value chain and marketing channels of perishables, while Carvalho (1992) research project proposal have a detailed description of the methodology to be used in sampling and measuring losses and a comprehensive literature review.

\section{Some remarks on the publications}

Brazilian publications on PHL have low international visibility because most of them are written in Portuguese, or are published in non-indexed journals or even are available only in printed forms in some libraries. Only a few papers on specific topics, such as logistics, waste and postharvest diseases, were published in English in peer reviewed journals. These may be some of the reasons why Kitinoja \& Kader (2015) had included only three Brazilian Portuguese-written references in their white paper on measuring postharvest losses in developing countries.

Moreover, most of the scientific papers on the subject were published in Brazilian journals of different areas of knowledge (Agricultural Sciences, Horticulture, Plant Physiology, Plant Pathology, Economics, Management). These journals have distinct quality standards in major publishing processes, such as peer review and editing. Just to give an example, there are at least 15 Brazilian journals listed at the Scientific Electronic Library Online (SciELO) (www.scielo.br) which may publish papers on Postharvest Sciences. At the same time, Brazilian scientists are too prolific, since most of the evaluations for research grants or career progress are based in number of published papers. For all these reasons, citations of Brazilian documents on PHL are rare in international publications, including those of leading institutions, such as the
FAO, for example.

Most of the publications on PHL in Brazil can be regarded as grey literature, since they are not peer-reviewed, indexed or easily accessed. Furthermore, from 1970 to 1999 , most of the reports, thesis, dissertations, abstracts and technical documents were published in printed forms, only available in hard copies in some libraries. After the 2000s, non-print media became more popular and accessible in Brazil, but even with this progress it is difficult to find relevant publications on the subject.

\section{A new scenario for postharvest losses in Brazil?}

The production, distribution and commercialization of horticultural products in Brazil have undergone great transformations in the last two decades. Until the 1990s, the traditional marketing channel was basically composed by four main stages: farmers $>$ wholesalers $>$ retailers $>$ consumers. In the last decades, the concentration of commercialization of horticultural products by the supermarkets promoted dramatic changes in the productive systems. Major supermarket chains have adopted different strategies and processes for the acquisition of fresh fruits and vegetables, such as the installation of exclusive distribution centers, sale on consignment, direct purchase of local producers, purchase of exclusive suppliers of fresh-cut and organic system, outsourced production and marketing with own brands for some fruits and vegetables, among others.

Furthermore, Brazil is a country of continental dimensions, with marked regional differences in production, distribution and consumption of fresh fruits and vegetables. Traditional value chains for perishables still exist all over the country, with distinct technological levels depending on the commodity. State-owned wholesale markets used to be the main market structure within each Brazilian federative state, and CEAGESP, in São Paulo, still works as a hub. This complex web of channels had underwent some changes in the last decades but still plays an important role in supplying the domestic market and price setting.

At present, fresh produce market is 
highly segmented by consumer's social classes, farming systems (conventional, organic, smallholders) and also distinct for metropolitan areas and countryside municipalities. Thus, it would be advisable to perform new studies on PHL including both traditional and new marketing channels adopted by the main retail players within each region.

Postharvest losses: which paths to walk through?

Despite advances in public food security policies in recent years in Brazil, PHL of horticultural products continue to be a challenge for society and governments. The cyclic political and economic crises faced by the country in recent decades have been promoting changes in food consumption patterns and in the agricultural productive system. As a consequence, the adoption of technologies that could positively impact the reduction of PVL is highly unpredictable.

Brazil currently has a reasonable capacity to generate knowledge and technologies in Postharvest Sciences, as a result of the RD\&I strengthening by universities and research institutions. Reduction of losses could lessen the pressure on food prices or at least provide more nutritious meals for many. However, under the current economic crisis circumstances, it seems unlikely that this type of research will be financed with public resources. At the same time, perhaps one of the greatest difficulties in facing this problem is precisely the convergence of interests between the private sector, government and science representatives.

For the private sector, the interest in reducing losses goes directly to business efficiency and the adequate supply of consumer demands. Science tends to particularize and address the phenomenon only from a technical point of view, without taking into account powerful vectors, such as economic feasibility in adopting technologies and identification of potential beneficiaries. Another limitation of science is the tendency to study only part of the phenomena, with a reductionist view, in a complex area with an immense interface, which ranges from farmers in the production units to consumers at the end of the chain.

It would also be opportune to rethink the Brazilian agrifood system in a more comprehensive way, including discussing production systems and consumption and its alignment with public food security policies. At the present situation, high rates of postharvest losses and food waste occur simultaneously with the negative impacts of the economic crisis on food prices, which could increase again poverty and food insecurity in the country. Another relevant phenomenon is the culture of food waste present in all social classes in Brazil, including the poorer (Porpino et al., 2015).

In conclusion, we have already published a lot about postharvest losses of horticultural products in Brazil, covering a wide range of subjects, such as loss estimates and measurements, application of postharvest technologies, studies on economic consequences of losses, among others. Nevertheless, all these compiled information on losses only allow us to have some pictures from the past, insufficient to understand such complex theme at the present time. Periodical updates on the assessments of postharvest systems of horticultural products, as well as consumption trends that directly impact the production and marketing are necessary to have a comprehensive overview of PHL. It is certainly a continuous challenge that requires the involvement of all society and governments.

\section{REFERENCES}

BORGES, RF. 1991. Panela Furada: o incrível desperdício de alimentos no Brasil. São Paulo: Editora Columbus. 124p. (Coleção Cardápio, 7).

BRANDT, SA; LADEIRA, HH; LAPA, AJ; VALLE, JR; REZENDE, AM; RIBEIRO, FB; NETO AAAD. 1974. Estimativas de perdas na comercialização de hortaliças no mercado de Manaus. Revista Seiva 82: 1-14.

CAIXETA FILHO, JV. 1999. Losses in the transportation of fruits and vegetables: a Brazilian case study. International Journal of Logistics: Research and Applications 2: 325-341.

CARVALHO, FC. 1992. Avaliação de perdas pós-colheita de hortigranjeiros no estado de São Paulo. São Paulo: IEA. 46p. (Projeto de Pesquisa).
CENCI, AS; SOARES, AG; FREIRE JUNIOR, M. 1997. Manual de Perdas Pós-Colheita de Frutos e Hortaliças. Rio de Janeiro: CTAA/Embrapa. 29p. (CTAA. Embrapa. Documentos, 27).

CHITARRA, MIF; CHITARRA, AB. 1990. PósColheita de Frutos e Hortaliças - Fisiologia e Manuseio. Lavras: ESAL/FAEPE. 320p.

CHITARRA, MIF; CHITARRA, AB. 2005. PósColheita de Frutos e Hortaliças - Fisiologia e Manuseio. $2^{\mathrm{a}}$ edição. Lavras: ESAL/FAEPE. $785 \mathrm{p}$.

COSTA, FG; CAIXETA FILHO, JV. 1996. Análise das perdas na comercialização de tomate: um estudo de caso. Informações Econômicas 26: 9-24.

FAO. 2011. Global Food Losses and Food Waste - Extent, Causes and Prevention. Rome: FAO. 38p.

FOSCACHES, CAL; SPROESSER, RL; QUEVEDO-SILVA, F; LIMA FILHO, DO. 2012. Logística de frutas, legumes e verduras (FLV): um estudo sobre embalagem, armazenamento e transporte em pequenas cidades brasileiras. Informações Econômicas 42: 37-46.

FREIRE JUNIOR, M; SOARES, AG. 2014. Orientações quanto ao manuseio pré- e póscolheita de frutas e hortaliças visando redução de suas perdas. Rio de Janeiro: Embrapa Agroindústria de Alimentos. 5p. (Embrapa Agroindústria de Alimentos. Comunicado Técnico, 205).

HENZ, GP. 2015. Perishables postharvest losses in Brazil: a review and a current view of an old problem. In: FIRST INTERNATIONAL CONGRESS ON POSTHARVEST LOSS PREVENTION, 1. Proceedings... Rome, Italy: ADM Institute for the Prevention of Postharvest Loss, University of Illinois, Urbana-Champaign. p. 6-8.

HLPE. 2014. Food losses and waste in the context of sustainable food systems. A report by the High Level Panel of Experts on Food Security and Nutrition of the Committee on World Food Security. Rome: FAO. 116p.

KITINOJA, L; KADER, AA. 2015. Measuring postharvest losses of fresh fruits and vegetables in developing countries. The Postharvest Education Foundation. 26p. (PEF White Paper 15-02).

LANA, MM. 2013. Desafios da pós-colheita de hortaliças no Brasil. Horticultura Brasileira 31(4): cover article.

LANA, MM. 2016. Estação de trabalho: infraestrutura para beneficiamento de hortaliças em pequenas propriedades rurais. Horticultura Brasileira 34: 443-447.

LANA, MM; BARROS, D; MOITA, AW; NASCIMENTO, EF; SOUZA, GS; VILELA, NJ. 1999. Nivel e valores de perdas póscolheita em supermercados da rede varejista do Distrito Federal. Brasília: Embrapa Hortaliças. 22p. (Research Project Final Report).

LANA, MM; MOITA, AW; NASCIMENTO, EF; SOUZA, GS; MELO, MF. 2002. Identificação das causas de perdas pós-colheita de cenoura no varejo, Brasília-DF. Horticultura Brasileira 20: 241-245. 
LUENGO, RFA; CAlBo, AG. 2013. PósColheita de Hortaliças - 500 Perguntas 500 Respostas. Brasília: Embrapa Informação Tecnológica. 254p.

MARTINS, CR; FARIAS, RM. 2002. Produção de alimentos x desperdício: tipos, causas e como reduzir perdas na produção agrícola - revisão. Revista da FZVA, Uruguaiana, 9: 20-32.

MUKAI, MK; KIMURA, S. 1986. Investigação das práticas pós-colheita e desenvolvimento de um método para análise de perdas de produtos hortícolas. Viçosa-MG, Brazil: CENTREINAR. 253p. (Technical Report).

PÉRA, TG; GAMEIRO, AH; BACCHI, DB; ROCHA, FV; CAIXETA FILHO, JV. 2015. An overview of the state-of-art of post-harvest losses in Brazil. In: FIRST INTERNATIONAL CONGRESS ON POSTHARVEST LOSS PREVENTION, 1. Proceedings... Rome,
Italy: ADM Institute for the Prevention of Postharvest Loss, University of Illinois, Urbana-Champaign. p. 39-40.

PORPINO, G; PARENTE, J; WANSINK, B. 2015. Food waste paradox: antecedents of food disposal in low income households. International Journal of Consumer Studies 39: 619-629. (DOI: 10.1111/ijcs.12207).

RESENDE, LMA. 1979. Causas e Efeitos de Perdas na Comercialização de Produtos Hortícolas. Viçosa: UFV. 68p. (Tese mestrado).

REZENDE, JB. 1992. Avaliação das perdas de produtos agrícolas em Minas Gerais. Belo Horizonte: Fundação João Pinheiro. 122p.

SILVA, JVR; MARTINS, RS. 2010. A contribuição das melhorias das práticas logísticas à política pública de segurança alimentar. XIII Simpósio de Administração da Produção, Logística e Operações Internacionais, São
Paulo. 16p.

SUDENE. 1971. Avaliação dos índices de perdas dos produtos hortifrutigranjeiros comercializados na cidade de Recife-PE. Recife, Brazil. 59p. (Technical Report).

TSUNECHIRO, A; UENO, LH; PONTARELLI, CTG. 1994. Avaliação econômica das perdas de hortaliças e frutas no mercado varejista da cidade de São Paulo, 1991-92. Agricultura em São Paulo 41: 1-15.

VILELA, NJ; LANA, MM; NASCIMENTO, EF; MAKISHIMA, N. 2003. O peso da perda de alimentos para a sociedade: o caso das hortaliças. Horticultura Brasileira 21: 141-143.

UENO, LH. 1976. Perdas na comercialização de produtos hortifrutícolas na cidade de São Paulo. Informações Econômicas 6: 5-7. 